\title{
Homenagem ao Mestre Sternberg
}

Faleceu no último dia 2 de março deste ano, na Califórnia, aos 93 anos, o professor Hilgard O`Reilly Sternberg, do Departamento de Geografia da Universidade da Califórnia Berkeley, conforme divulgado no Jornal da USP de 21 a 27 de março de 2011.

Sternberg era conhecido por seus estudos amazônicos e por sua defesa dos aspectos ecológicos. Entretanto, há um aspecto não aparente em suas publicações, que se destacou em seus ensinamentos e cursos, que é a relação da Geografia com a Saúde Pública, em temas dos mais atuais, de uma forma bastante pioneira.

Durante meu mestrado na Universidade da Califórnia Berkeley, em finais dos anos 1970, sob sua orientação, tive o privilégio de cursar duas de suas disciplinas, oferecidas então pela primeira vez, naquele campus, que me despertaram para esta área interdisciplinar da Geografia e Saúde Pública.

A disciplina Geography of Health and Disease, foi ministrada de forma conjunta por docentes da Faculdade de Medicina e do Departamento de Geografia da Universidade da Califórnia. Nela, foram abordados aspectos variados de saúde e doença em suas relações com o espaço geográfico. Temas como Antropologia da Saúde, Cartografia aplicada ao entendimento de endemias e epidemias e à distribuição de serviços de saúde; turismo voltado à prevenção e cura de doenças; doenças crônico-degenerativas e transições demográfica e epidemiológica, dentre outros, foram dados em aula e aprofundados em leituras instigantes. Foi este curso que me levou para a pesquisa em Geografia Médica, área da Geografia que estava pouco em evidência no Brasil à época em que realizei meu doutorado no Laboratório de Climatologia do Departamento de Geografia da Universidade de São Paulo, nos anos 1980. Meu orientador na tese "Poluição do ar e doenças respiratórias em crianças: um estudo de Geografia Médica” foi José Roberto Tarifa, mas Sternberg e seus ensinamentos foram inspiradores do tema e orientadores do referencial teórico.

Outra disciplina oferecida por Sternberg, que cursei em Berkeley, foi Geography of Food and
Nutrition. No final da década de 1970, Sternberg já tratava de assuntos que só atualmente começam a ser discutidos no Brasil, tais como: o consumo elevado de carne bovina como indutor do desmatamento na Amazônia; o papel negativo da estratégia mercadológica das grandes empresas alimentícias multinacionais na dieta dos países em desenvolvimento; a homogeneização e a redução das diferenças espaciais no padrão de alimentação dos povos e regiões; a perda do valor nutricional dos alimentos com seu super processamento e, sobretudo; o embricamento das questões nutricionais com as questões ambientais.

Sternberg teve poucos de seus trabalhos publicados no Brasil e um de seus sonhos era sua maior divulgação no país de seu nascimento e de seu coração. Por isso, em 2006, iniciamos um projeto de livro, por mim coordenado e denominado de "Estudos Amazônicos: dinâmica natural e impactos socioambientais". Nele reuni alguns de seus resultados de pesquisa mais significativos sobre a Amazônia, para tradução e publicação pela Editora da Universidade de São Paulo. Infelizmente, o livro, em sua fase final, não foi publicado antes de seu falecimento. Esperamos lançá-lo em Julho, quando seu filho, que encampou o projeto, vier ao Brasil depositar suas cinzas na Ilha do Careiro, em Manaus, como foi seu desejo.

Direta ou indiretamente, por meio de alunos, exalunos e escritos, Sternberg foi um dos inspiradores de uma área que tem crescido bastante, mais recentemente, no Brasil, que é a integração da Geografia com a Saúde Pública, retomando estudos pioneiros do médico e geógrafo Josué de Castro, ou avançando em análises espaciais por meio de modernas tecnologias de informação, tais como o geoprocessamento e os Sistemas de Informação Geográfica.

\section{Helena Ribeiro}

Coordenadora do Laboratório de Geoprocessamentos - LABGEO do Departamento de Saúde Ambiental da Faculdade de Saúde Pública da USP

São Paulo, 27 de março de 2011. 